\title{
Hepatitis C virus (HCV) genotypes distribution: an epidemiological up-date in Europe
}

\author{
Arnolfo Petruzziello* ${ }^{*}$, Samantha Marigliano, Giovanna Loquercio and Carmela Cacciapuoti
}

\begin{abstract}
Hepatitis C virus (HCV) infection is a major public health burden in Europe, causing an increasing level of liver-related morbidity and mortality, characterized by several regional variations in the genotypes distribution. A comprehensive review of the literature from 2000 to 2015 was used to gather country-specific data on prevalence and genotype distribution of HCV infection in 33 European countries (about $80 \%$ of the European population), grouped in three geographical areas (Western, Eastern and Central Europe), as defined by the Global Burden of Diseases project (GBD).

The estimated prevalence of HCV in Europe is $1.7 \%$ showing a decrease than previously reported $(-0.6 \%)$ and accounting over 13 million of estimated cases. The lowest prevalence $(0.9 \%)$ is reported from Western Europe (except for some rural areas of Southern Italy and Greece) and the highest (3.1\%) from Central Europe, especially Romania and Russia. The average HCV viraemic rate is $72.4 \%$, with a population of almost 10 million of HCV RNA positive patients.

Genotype distribution does not show high variability among the three macro-areas studied, ranging between $70.0 \%$ (Central Europe), 68.1 \% (Eastern Europe) and 55.1 \% (Western Europe) for genotype 1, $29.0 \%$ (Western Europe), $26.6 \%$ (Eastern Europe) and $21.0 \%$ (Central Europe) for genotype 3. Genotype 2 seems, instead, to have a major prevalence in the Western Europe (8.9\%), if compared to Eastern (4.3\%) or Central (3.2\%), whereas genotype 4 is present especially in Central and Western area ( $4.9 \%$ and $5.8 \%$, respectively).

Despite the eradication of transmission by blood products, HCV infection continues to be one of the leading blood-borne infections in Europe. The aim of this review is, therefore, to provide an update on the epidemiology of HCV infection across Europe, and to foster the discussion about eventual potential strategies to eradicate it.
\end{abstract}

Keywords: HCV genotype, Epidemiology, Hepatitis C virus, HCV prevalence, Viraemia, HCV infections

\section{Background}

Hepatitis $\mathrm{C}$ virus (HCV) is one of the major globally prevalent pathogen and one of the main leading cause of death and morbidity also in Europe [1-3]. According to some estimates, about 3-4 million people are newly infected every year worldwide, and over 350,000 patients yearly die due to HCV-related disorders [4]. The last estimates of disease burden showed an increase in seroprevalence over the last 15 years to $2.8 \%$, equating to $>185$ million infections worldwide [5].

\footnotetext{
* Correspondence: a.petruzziello@istitutotumori.na.it

Virology and Molecular Biology Unit "V. Tridente", Istituto Nazionale Tumori Fondazione "G. Pascale", IRCCS Italia, Via Mariano Semmola, 80131 Naples, Italy
}

(c) 2016 The Author(s). Open Access This article is distributed under the terms of the Creative Commons Attribution 4.0 International License (http://creativecommons.org/licenses/by/4.0/), which permits unrestricted use, distribution, and reproduction in any medium, provided you give appropriate credit to the original author(s) and the source, provide a link to the Creative Commons license, and indicate if changes were made. The Creative Commons Public Domain Dedication waiver (http://creativecommons.org/publicdomain/zero/1.0/) applies to the data made available in this article, unless otherwise stated. long term hepatic and extrahepatic consequences $[6,7]$. Persistent HCV infection is generally associated with the development of liver cirrhosis, hepatocellular carcinoma $(\mathrm{HCC})$, liver failure, and death [8], and a significant portion of liver transplantation in Europe is attributable to disorders related to Chronic Hepatitis $\mathrm{C}(\mathrm{CHC})$ [9]. The limited effectiveness of treatments available until a couple of years ago have led HCV-associated mortality to exceed that due to the human immunodeficiency virus (HIV) in developed countries.

The incidence of complications of $\mathrm{CHC}$ will not decline over the next 10 years despite improved efficacy of antiviral therapy because most patients with $\mathrm{CHC}$ 
remain undiagnosed [10]. In addition, the clinical impact of some extrahepatic disorders, leading to renal, cardiac and cerebrovascular outcomes associated with cryoglobulinemia and diabetes, has been emphasized only recently $[4,5,11,12]$ and traditionally neglected in cost-effectiveness analyses.

Although a recent meta-analysis indicates the global incidence rate of HCV infection decreasing [13], mathematic models show that deaths from liver disease secondary to $\mathrm{HCV}$ infection will continue to increase over the next 20 years $[14,15]$. This means that, although many data suggest that $\mathrm{HCV}$ infection could be eliminated in the next 15-20 years with focused strategies to cure current infections and prevent new infections [16, 17], a good understanding of $\mathrm{HCV}$ epidemiology should be required to develop strategies to eradicate $\mathrm{HCV}$.

The epidemiological status of $\mathrm{HCV}$ infection in Europe is continuously evolving and may vary significantly region by region. In the last years several studies have reported level prevalence estimates of $\mathrm{HCV}$ infections in Europe, but always considering a limited number of countries or specific risk groups [18-23]. A more recent analysis, instead, estimates a global and also European $\mathrm{HCV}$ prevalence, but provides only regional estimates [3]. In all these cases, however, studies were focused only on the presence of $\mathrm{HCV}$ antibodies that generally overestimates the disease burden because they include also patients healed spontaneously or through treatments. So, although antibodies to $\mathrm{HCV}$ (anti-HCV) are actually the most commonly available marker of HCV infection and often used both to estimate the prevalence of anti-HCV in population-based studies and to compare HCV infection levels globally, the most important indicator of HCV diffusion seems to be its classification into different genetic variants.

$\mathrm{HCV}$ exhibits an extraordinarily high degree of genetic diversity [24]. Its strains are classified into seven recognized genotypes on the basis of phylogenetic and sequence analyses of whole viral genomes $[25,26]$. HCV strains, belonging to different genotypes, differ at 30-35\% of nucleotide sites. Within each genotype, $\mathrm{HCV}$ is further classified into 67 confirmed and 20 provisional subtypes. Strains that belong to the same subtype differ at $<15 \%$ of nucleotide sites [27].

Since, actually, the duration of treatment and the need for adjuvant interferon and ribavirin with the new direct-acting antiviral (DAA) therapies still remain dependent in part on HCV genotype and subtype, it is clear how a better knowledge of the epidemiology of $\mathrm{HCV}$ and of the distribution of its genotypes could substantially contribute to an effective control of this troubling pandemic especially by focusing screening strategies on patients at risk of disease progression, in order to get them into earlier treatment.
Because epidemiological data are the basis for the development of preventive strategies able to eradicate $\mathrm{HCV}$ infection, the aim of this study is to systematically up-date and review $\mathrm{HCV}$ epidemiology throughout Europe to foster the development of country-specific screening programs and an international $\mathrm{HCV}$ surveillance program.

\section{Methods}

A comprehensive review of the literature from 2000 to 2015 was used to gather country-specific data on prevalence, number of diagnosed individuals and genotype distribution. References were identified through two sources: indexed journals and non-indexed sources. Indexed articles were found by searching Pub Med and regional databases using the following terms: "[Country Name] and [hepatitis c or HCV] and [prevalence]" or [genotypes] or [viraemia]". Furthermore, references cited within the articles were used.

Regions included in the analysis were those defined by the Global Burden of Diseases, Injuries, and Risk Factors 2010 (GBD) study. This study defined in Europe three regions (Western, Eastern and Central) that were "epidemiologically homogenous as possible so that information from detailed studies in one country can plausibly be extrapolated to other countries in the region to create burden estimates that are useful to individual countries in planning for health sector activities" [28-30].

The average $\mathrm{HCV}$ prevalence and viraemic rate for each region were calculated by dividing the sum of data reported from each country to the total number of countries within the region.

Article titles and abstracts were reviewed for relevance and the following data were extracted from full articles or abstracts:anti-HCV prevalence, viraemic prevalence, viraemic rate and genotypes distribution.

Studies in non-representative populations (e.g., people who inject drugs (PWID's), haemophiliacs, minority ethnic groups, blood donors, etc.) or with a sample size of less than 1000 and studies published prior to 2000 or not in English were excluded from the analysis.

Five hundred twenty nine articles were selected from 33 countries based on relevance. In addition, nonindexed sources were identified through searches of individual country's Ministry of Health's websites and international health agency reports. If articles contained the same patient cohort then this cohort was only counted once. No representative data were available from six countries (Albania, Bosnia and Herzegovina, Estonia, Iceland, Macedonia and Montenegro).

Because the first- and second generation immunoassay tests may provide false-positive results, which can overestimate the total infected population, care was taken to 
use only studies that used the latest generation tests to estimate the country's prevalence.

In the majority of studies $\mathrm{HCV}$ cases were classified at the genotype level, but not at the subtype level, so we decided to use only genotype classification using as general method that proposed by Simmonds et al. [25]. In case of one or more genotypes identified in the same patient, we classified it as "mixed". We did not include genotype 7 in the analysis.

\section{General epidemiology of Hcv in Europe}

The GBD subdivides Europe into 3 main areas: Central, Eastern and Western. The collected data were segmented by country according to prevalence, $\mathrm{HCV}$ genotype distribution and viraemic rate. The European Center for Disease Prevention and Control (ECDC) provided incidence rates for the European countries and their estimates were used for newly diagnosed populations because most countries did not distinguish between chronic and acute cases of HCV infection.

Surveillance systems also vary widely between and within countries in Europe. A publication by ECDC documented 38 different surveillance systems in 27 countries; six countries had more than one system [22]. Surveillance systems, besides, vary by structure, reporting practices, data collection methods and case definitions used [31]. For these reasons, caution should be exercised when comparing case reporting data across countries.

The estimated prevalence of HCV of the whole continent is 1.7 \%, ranging from $3.1 \%$ in Eastern Europe to $0.9 \%$ in Western Europe, accounting over 13 millions of estimated cases. The average $\mathrm{HCV}$ viraemic rate is $71.3 \%$, with a population of almost 10 million of $\mathrm{HCV}$ RNA positive patients (Table 1).

The predominant genotype is genotype 1 (G1) (64.4\%), followed by genotype 3 (G3) (25.5 \%), 2 (G2) (5.5\%) and 4 (G4) (3.7\%). Only small percentages of genotype 5 (G5), genotype 6 (G6) and mixed or not further classified genotypes are reported (Table 2).

Genotype distribution does not show high variability among the three macro-areas studied, ranging between $70.0 \%$ (Central Europe), $68.1 \%$ (Eastern Europe) and $55.1 \%$ (Western Europe) for G1, $29.0 \%$ (Western

Table 1 HCV Seroprevalence and viraemic rate in Europe

\begin{tabular}{lcc}
\hline Regions & $\begin{array}{c}\text { Anti - HCV } \\
\text { Prevalence (\%) }\end{array}$ & $\begin{array}{c}\text { Viraemic } \\
\text { Rate (\%) }\end{array}$ \\
\hline Europe, Central & 1.2 & 73.3 \\
Europe, Eastern & 3.1 & 69.6 \\
Europe, Western & 0.9 & 71.0 \\
Total Europe & 1.7 & 71.3 \\
\hline
\end{tabular}

Europe), 26.6 \% (Eastern Europe) and $21.0 \%$ (Central Europe) for G3.

G2 seems to have a major prevalence in the Western Europe (8.9 \%), if compared to Eastern (4.3\%) or Central (3.2 \%), whereas G4 is present especially in Central and Western area (4.9\% and 5.8, respectively).

Only few cases of G5 and G6 are reported and mainly from Western area (Table 2).

\section{Central Europe}

This large area, including countries like Albania, Bulgaria, Bosnia and Herzegovina, Czech Republic, Croatia, Hungary, Macedonia, Montenegro, Poland, Romania, Serbia, Slovakia and Slovenia, shows a prevalence of $\mathrm{HCV}$ infection of $1.2 \%$, varying between $3.2 \%$ in Romania and $0.5 \%$ in Serbia and an average viraemic rate estimated at $73.3 \%$ (Table 3 ). We did not found representative data concerning the $\mathrm{HCV}$ prevalence from published studies in Albania, Bosnia and Herzegovina, Macedonia and Montenegro.

The predominant genotypes in this area is G1 (70.0\%), followed by G3 (21.0\%), G4 (4.9\%) and G2 (3.2\%). Only a small percentage of mixed genotypes and G6 has been found, whereas no G5 cases are reported (Fig. 1). In Romania, Hungary and Slovakia, G1 is almost the only genotype found $(98.0,94.1$ and $89.9 \%$, respectively). A considerable percentage of G3 was described in Macedonia (44.6\%), Slovenia (37.8 \%) and Croatia (35.6\%), while a significant prevalence of G2 was described only in Albania (20.0\%) and of G4 in Montenegro (19.6\%) and Albania (16.0\%).

No genotypes distribution data are available from Bulgaria.

\section{Eastern Europe}

The prevalence of $\mathrm{HCV}$ infection in this zone, including Belarus, Estonia, Lithuania, Latvia, Moldova, Russia and Ukraine, is $3.1 \%$, ranging between $4.5 \%$ in Moldova and $1.3 \%$ in Belarus, with a viraemic rate estimated at $69.6 \%$ (Table 4). No adult HCV prevalence and/or viraemic data are available from Estonia.

The predominant genotypes in this area is G1 (68.1\%), followed by G3 (26.6 \%) and G2 (4.3\%). Only a small percentage of mixed genotypes and G4 (0.5\%) are reported, whereas no G5 and G6 cases has been described (Fig. 2).

Only in Latvia G1 is the dominant genetic variant (89.2\%). A considerable percentage of G3 was described in Belarus (38.5\%) and Russia (35.1\%).

No genotypes distribution data are available from Moldova and Ukraine.

\section{Western Europe}

The countries studied in this area were Austria, Belgium, Cyprus, Denmark, Finland, France, Germany, Greece, 
Table 2 Prevalence of HCV genotypes in Europe

\begin{tabular}{lccccccc}
\hline Continents & G1 (\%) & G2 (\%) & G3 (\%) & G4 (\%) & G5 (\%) & G6 (\%) & Mixed \\
\hline Central Europe & 70.0 & 3.2 & 21.0 & 4.9 & - & 0.1 & - \\
Eastern Europe & 68.1 & 4.3 & 26.6 & 0.5 & - & 0.5 \\
Western Europe & 55.1 & 8.9 & 29.0 & 5.8 & 0.2 & 0.1 & 0.8 \\
Total Europe & 64.4 & 5.5 & 25.5 & 3.7 & 0.1 & 0.1 & 0.7 \\
\hline
\end{tabular}

Iceland, Ireland, Italy, Luxembourg, The Netherlands, Norway, Portugal, Spain, Sweden, Switzerland and United Kingdom.

The prevalence of $\mathrm{HCV}$ in the general population of this area is $0.9 \%$, ranging between $2.0 \%$ in Italy and $0.2 \%$ in The Netherlands, with a viraemic rate estimated at $71.0 \%$ (Table 5). No representative data concerning the $\mathrm{HCV}$ prevalence from published studies were found from Iceland.

The predominant genotypes is G1 (55.1\%), followed by G3 (29.0\%), G2 (8.9 \%) and G4 (5.8\%), whereas only small percentages of G5, G6 and mixed genotypes are reported (Fig. 3). In Austria, Spain, Germany and Italy G1 is over the sixty percent of all the genotypes found. A considerable percentage of G3 was described in some of the countries of the Northern Europe, as Finland (46.0\%), United Kingdom (43.8 \%), Denmark (43.0\%), whereas only Italy shows a significant percentage of G2 (26.0\%).

No genotypes distribution data are available from Cyprus.

\section{Discussion and conclusions}

Hepatitis $\mathrm{C}$ virus (HCV) infection is one of the major public health burden in Europe, causing an increasing level of liver-related morbidity and mortality due to the disease progression [32-38].

Table 3 HCV prevalence/infected population in Central Europe (adjusted for the adult population)

\begin{tabular}{cllll}
\hline Region/Country & $\begin{array}{l}\text { Number of } \\
\text { studies }\end{array}$ & $\begin{array}{l}\text { Anti-HCV } \\
\text { prevalence (\%) }\end{array}$ & $\begin{array}{l}\text { Anti-HCV infected } \\
\text { (thousands) }\end{array}$ & $\begin{array}{l}\text { Viraemic } \\
\text { rate (\%) }\end{array}$ \\
\hline Central Europe & 31 & 1.2 & 1188.7 & 73.3 \\
Bulgaria & 3 & 1.1 & 67 & - \\
Croatia & 1 & 0.9 & 38.2 & - \\
Czech & 1 & 0.7 & 60 & 70.0 \\
Republic & & & & 84.6 \\
Hungary & 6 & 0.8 & 68 & 70.0 \\
Poland & 10 & 0.9 & 279 & 91.3 \\
Romania & 5 & 3.2 & 575 & - \\
Serbia & 1 & 0.5 & 35.5 & 49.2 \\
Slovakia & 1 & 1.4 & 66 & 74.6 \\
Slovenia & 3 & - & - & \\
\hline
\end{tabular}

The HCV disease paradigm varies by country based on historical and present risk factors, screening programs and treatment rates. Individual countries must consider appropriate country-specific prevention, diagnosis and treatment strategies to reduce the disease burden represented by HCV. Unfortunately, in many countries, there is a lack of robust epidemiological data upon which to base these strategies. Many studies have examined regional $\mathrm{HCV}$ infection rates [39-42], but they have typically focused on quantifying the anti-HCVprevalence with no attention to $\mathrm{HCV}$ genotypes distribution.

Here we have provided a comprehensive review of HCV epidemiology studies throughout Europe between 2000 and 2015 with a special care to not base our study only on available data but instead trying to analyze only the relevant data. In fact, although $\mathrm{HCV}$ prevalence among blood donors, available in many countries, represents surely an attractive data source for the large sample size, all the studies concerning only this subgroup were excluded because this population, corresponding to healthy screened adults, is not representative of the total population. For the same reason, on the contrary, numerous high risk populations studies (e.g. PWIDs, haemodialysis patients, cancer patients, etc.) were not considered too. Finally, all the studies published prior to 2000 were excluded considering the global epidemiological changes that HCV infections has had in the latest twenty years [43-45].

Studying 33 countries (9 in Central Europe, 6 in Eastern Europe, and18 in Western Europe), HCV prevalence in Europe is estimated at 1.7 \% (over 10 million of $\mathrm{HCV}$ infected adults). Our data suggest that the lowest $\mathrm{HCV}$ prevalence estimates are from Western European countries $(0.9 \%)$, while the highest from Eastern Europe (3.1\%), even if these percentages should probably be adjusted in the future given the limited evidentiary support, especially from some countries in Central and Eastern European bloc. The main shortcomings of majority of studies from these areas reside in the fact that data are often based on surveys conducted in selected groups [32-34]. Furthermore, many studies are outdated and have failed to take into consideration the influence of some recent drivers such as migratory 


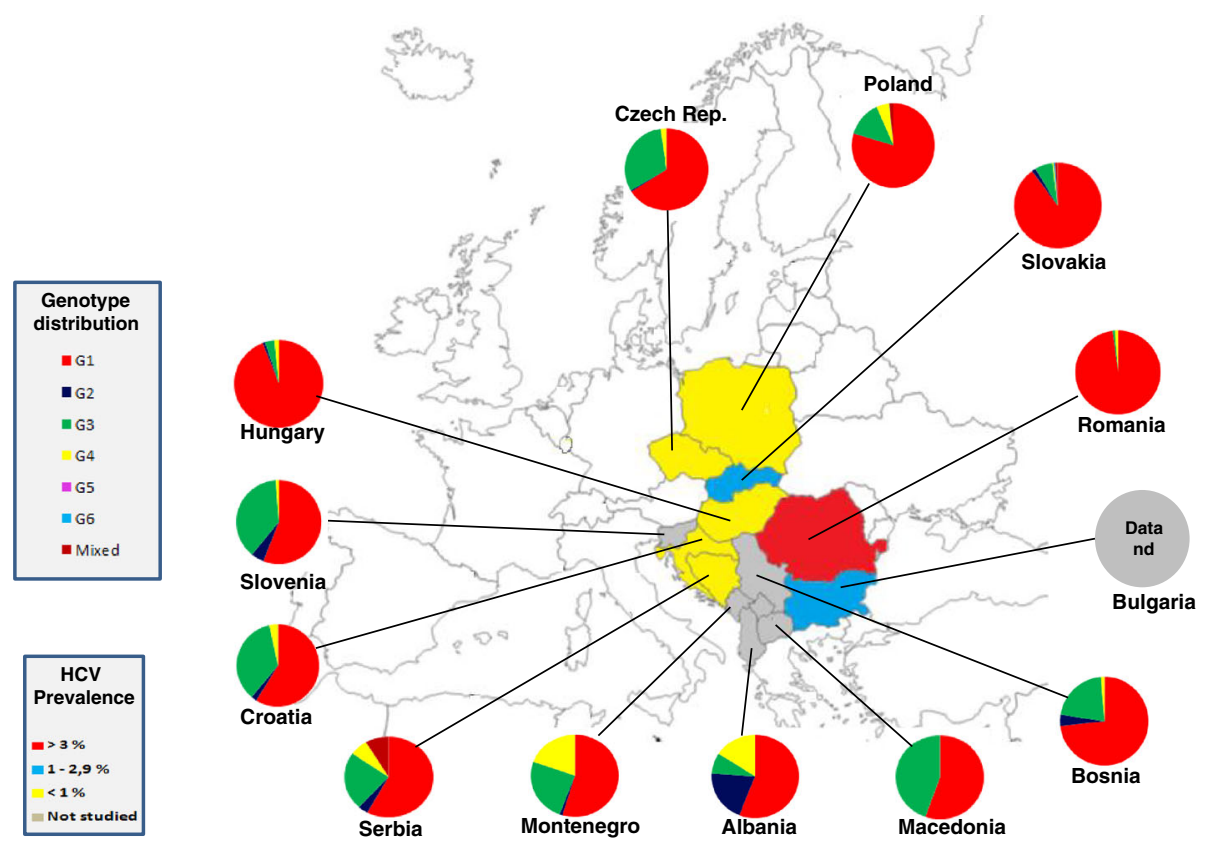

Fig. 1 Genotype distribution in Central Europe

movements, including those regarding war refugees and illegal human trafficking.

No adult HCV prevalence studies were available from 6 countries ( 1 both in Central and Western Europe and 4 in Eastern Europe), but in order of their contribution, the studied countries account for over the $80 \%$ of total European population.

Our analysis shows that the prevalence and number of $\mathrm{HCV}$ infected patients in Europe, if compared to a similar study concerning the period 1990-2005 and covering the geographical area of Europe defined by the WHO (i.e. including the former USSR republics) [5], has decreased from $2.6 \%$ (95 \% uncertainty interval [UI]: $2.4-2.9 \%$ ) to $1.7 \%$ (95 \% UI: $0.9 \%-3.1 \%$ ) and from 19 to 13 millions. It is interesting to note that the most relevant decrease has been observed in Western Europe $(-1.5 \%)$ and Central Europe (- $1.1 \%)$, whereas Eastern Europe countries register a moderate increase $(+0.2 \%)$.

Table 4 HCV prevalence/infected population in Eastern Europe (adjusted for the adult population)

\begin{tabular}{llcll}
\hline Region/Country & $\begin{array}{l}\text { Number of } \\
\text { studies }\end{array}$ & $\begin{array}{l}\text { Anti-HCV } \\
\text { prevalence (\%) }\end{array}$ & $\begin{array}{l}\text { Anti-HCV infected } \\
\text { (thousands) }\end{array}$ & $\begin{array}{l}\text { Viraemic } \\
\text { rate (\%) }\end{array}$ \\
\hline Eastern Europe & 20 & 3.1 & 6682 & 69.6 \\
Belarus & 2 & 1.3 & 100 & 69.0 \\
Latvia & 3 & 2.9 & 73 & 71.4 \\
Lithuania & 2 & 2.4 & 42 & - \\
Moldova & 2 & 4.5 & 130 & - \\
Russia & 8 & 4.1 & 4932 & - \\
Ukraine & 1 & 3.6 & 1385 & - \\
\hline
\end{tabular}

By estimating the total number of HCV RNA positive infections, our data show that the global average viraemic rate is at $72.4 \%$ (9.4 millions of HCV RNA positive cases), varying from $73.3 \%$ in Central Europe to 69.6 \% in Eastern Europe (Table 1). It is interesting notice that some countries, where it is reported an high anti-HCV prevalence, also have a low viraemic rate. The most interesting example is Poland where it was found an anti-HCV prevalence of $1.9 \%$ with a viraemic rate of $31 \%$ (a viraemic prevalence of $0.6 \%$ ) [42]. A more recent study conducted in the same country by using a confirmatory antibody test has showed an anti-HCV prevalence of $0.86 \%$ [46]. This example suggests the need to study viraemic infections since some historically high antibody prevalence estimates may be influenced by the use of low sensitive screening HCV tests.

Although these data seems to indicate a general decrease of HCV infection especially in Western Europe, a recent modelization has estimated how the numbers of HCV- mortality will increase in the next decades [15]. The disease progression model took into account the historical number of HCV infections, the age and gender distribution, the extent and impact of the movers of the $\mathrm{HCV}$ viraemic pool (i.e. so-called inputs and outputs, encompassing acute infections progressing to chronicity, migration movements, treatment uptake succeeding into viral eradication and deaths), the progression rates (based on literature data) and the all-cause mortality data gathered from the Human Mortality Database adjusted for incremental increases due to drug abuse and blood transfusion. This model was applied to several 


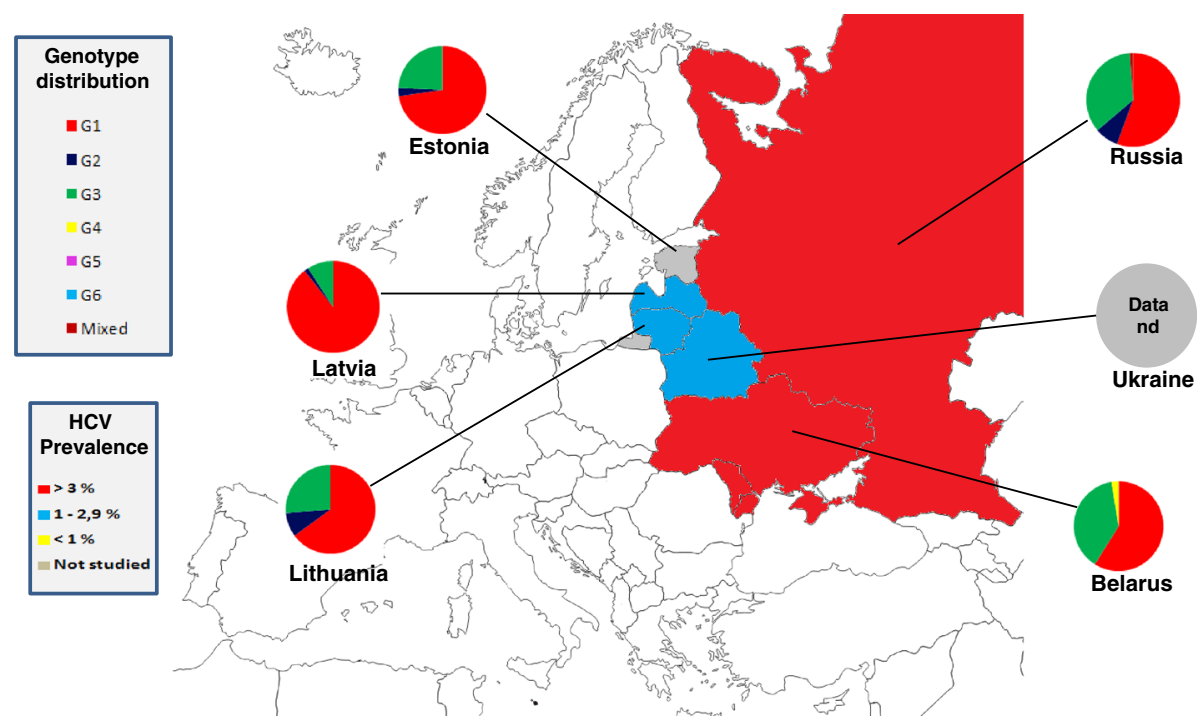

Fig. 2 Genotype distribution in Eastern Europe

major European countries (i.e. Austria, Belgium, England, France, Germany, Spain and others) [47]. According to this model, in the period 2013-2030, the number of decompensated cirrhosis, the prevalence of HCC in the general population and the liver-related morbidity rate will increase in Europe by $80 \%, 75 \%$ and $65 \%$, respectively. The only exception to this dreaded scenario is represented

Table 5 HCV prevalence/infected population in Western Europe (adjusted for the adult population)

\begin{tabular}{lllll}
\hline Region/Country & $\begin{array}{l}\text { Number of } \\
\text { studies }\end{array}$ & $\begin{array}{l}\text { Anti-HCV } \\
\text { prevalence (\%) }\end{array}$ & $\begin{array}{l}\text { Anti-HCV infected } \\
\text { (thousands) }\end{array}$ & $\begin{array}{l}\text { Viraemic } \\
\text { rate (\%) }\end{array}$ \\
\hline Western Europe & 478 & 0.9 & 3339 & 71.0 \\
Austria & 26 & 0.5 & 36 & 73.4 \\
Belgium & 15 & 0.9 & 86 & 80.0 \\
Cyprus & 2 & 0.6 & 5 & 71.4 \\
Denmark & 8 & 0.7 & 33 & 62.2 \\
Finland & 4 & 0.7 & 31 & - \\
France & 104 & 0.6 & 197 & 65.0 \\
Germany & 56 & 0.6 & 401 & 66.7 \\
Greece & 25 & 1.9 & 178 & - \\
Ireland & 7 & 1.1 & 40 & 75.0 \\
Italy & 124 & 2.0 & 1048 & 73.3 \\
Luxembourg & 1 & 0.9 & 4 & - \\
The Netherlands & 1 & 0.2 & 31 & - \\
Norway & 5 & 0.7 & 29 & 79.5 \\
Portugal & 4 & 1.8 & 164 & - \\
Spain & 51 & 1.7 & 688 & 68.6 \\
Sweden & 18 & 0.7 & 53 & 77.0 \\
Switzerland & 12 & 1.5 & 105 & - \\
United Kingdom & 15 & 0.6 & 210 & 68.5 \\
\hline
\end{tabular}

by France, where these parameters will decrease by $80 \%$, $85 \%$ and $75 \%$ in the same period, probably due to the large use of more potent antivirals.

A low diagnosis rate is obviously a major hurdle to implement strategies to fight the future health burden of $\mathrm{HCV}$. As shown recently [15], countries where is available a centralized registry, such as Austria, France, Germany and others north Europe countries, tend to boost the highest diagnosis rates (up to $80 \%$ for Sweden), while the lowest rates were reported for southern Europe countries, like Portugal (33\%). An useful strategy of screening should consider all patients with a history of exposure via the traditional routes of HCV infection, limiting the number of patients unaware of their infection, even if this approach is not useful to contain the increasing rate of mortality $\mathrm{HCV}$ related. For this purpose it would be necessary a more accurate analysis of the distribution of HCV genotypes and of their circulation in Europe, whose lack of data is one of the major health problems in Europe.

Concerning the genotype distribution, G1 accounts for $64.4 \%$ of all $\mathrm{HCV}$ infections among adults making it the most common, either in Central Europe $(70.0 \%)$ and in Western Europe (55.1\%). Even if here not reported, many data suggest that the subtypes $1 \mathrm{a} / 1 \mathrm{~b}$ ratio is dependent on patient age and transmission route, with a major prevalence of subtype G1b in older patients and of subtype G1a in PWIDs [48, 49].

G3 is the second most common genotype (25.5\%), ranging from $29.0 \%$ in Western Europe, $26.0 \%$ in Eastern and $21.0 \%$ in Central Europe. This is also one of the most challenging genotypes for therapy, since only sofosbuvir and daclatasvir are licensed for its treatment, and is often associated with faster rates of fibrosis 


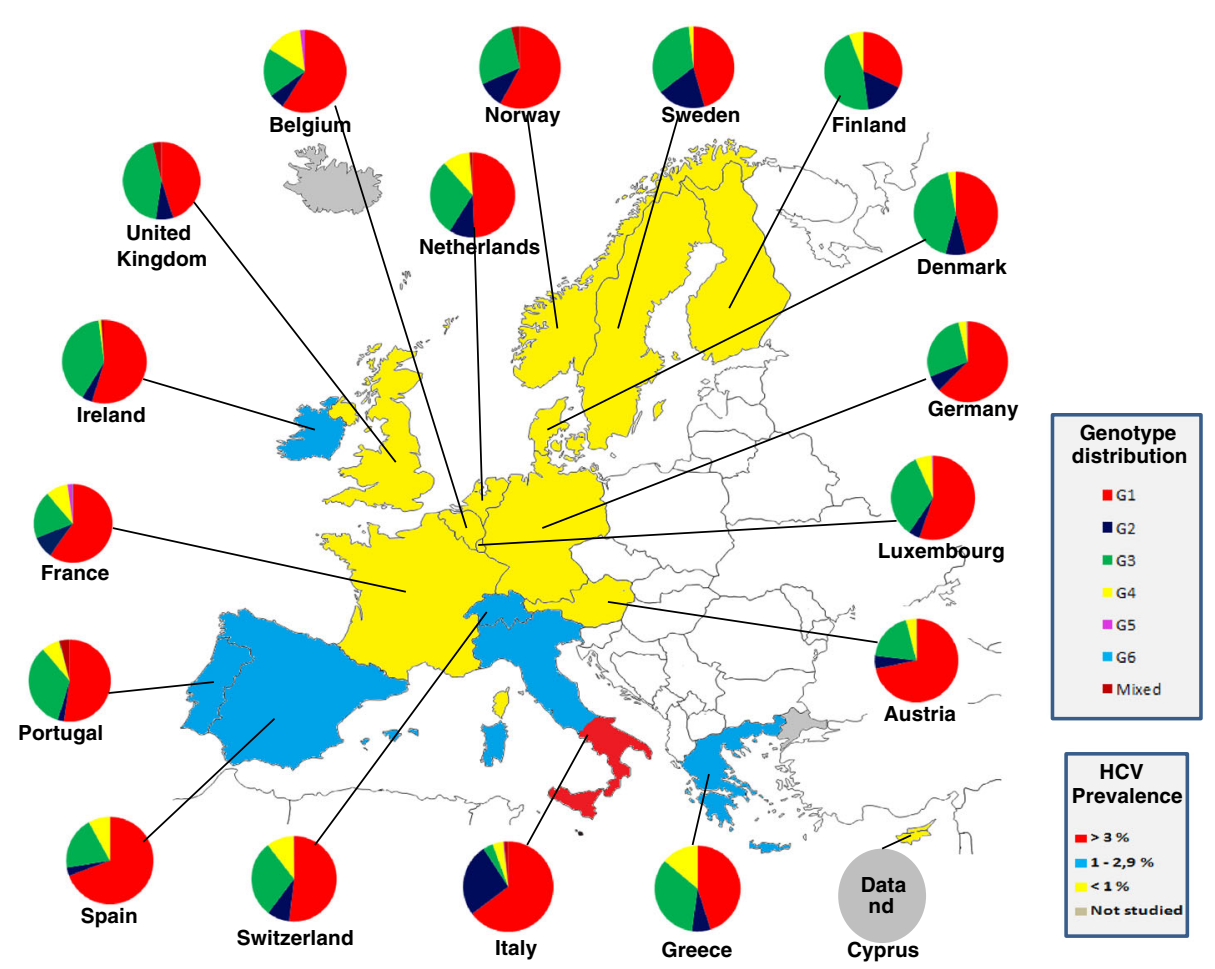

Fig. 3 Genotype distribution in Western Europe

progression and, as G1, higher prevalence of severe steatosis and hepatocellular carcinoma. G3 has been diagnosed more frequently in drug consumers in certain areas especially in West European countries [50,51].

G2 is the third most frequent genotype with percentages ranging from $8.9 \%$ in Western Europe to $3.2 \%$ in Central Europe [19, 52-54]. It is significantly associated to females, nosocomial infection or dental therapy and is mostly detected in older patients. Higher proportions of G2 were found in Sweden, Finland, Russia and in some of the ex soviet republics, probably in accordance to the Asian genotypes distribution, and in Italy $[55,56]$, especially in Southern areas $[57,58]$. G2 subtype 2c was probably introduced in Italy as a result of population movements during Italian colonialism at the end of the 19th century, and it did not spread there through intravenous drug use [59].

G4, instead, traditionally associated to Central Africa and the Middle East $[5,13,54]$ and mainly related to sexual practices, especially in MSM, and in HIV-coinfected patients [19], shows an average European proportion of around $3.7 \%$, ranging from $5.8 \%$ in Western Europe and $4.9 \%$ in Central Europe and only small percentage in Eastern Europe $(0.5 \%)$. A high prevalence of this genotype has been described in Belgium, Greece and The Netherlands (14.0\%, $13.9 \%$ and $10.5 \%$, respectively), but also in France and Spain (9.2 \% and $8.0 \%$ ), probably as consequence of three concomitant processes: increase in immigration from Northern and Central Africa, the use of drugs, and the introduction of G4 subtype d viruses into European networks of MSM and injection drug users [60].

Genotypes 5 and 6 were detected in extremely low frequencies and no association with independent epidemiological parameters was found.

It is necessary to clarify that in this study it was not possible to find a significant association between distribution of HCV genotypes and transmission route, since these data were clearly documented only for $25 \%$ of the studies. Furthermore, a clear classification of each genotype in subtypes was found available only for $40 \%$ of the selected studies. This lack of data has avoided a reliable subtypes distribution analysis, and also of "unresolved" or "mixed" infections that were not always clearly separated from double infections (unmistakable co- existence of two or more HCV strains).

In conclusion, HCV epidemiology shows a high variability across Europe, exhibiting a dynamic process influenced by traditional genotypes prevalence and evolving transmission trends. The early-nineties epidemics of GTs $1 \mathrm{~b}$ and 2, mainly related to nosocomial transmission, have been partially replaced by a scenario of GTs 1a, 3 and 4 where PWIDs and high-risk sexual practices are the main risk factor for HCV transmission [61, 62]. In fact, despite eradication of transmission by blood products, there is still an increase in $\mathrm{HCV}$ incidence in some 
countries, especially in Eastern Europe, probably due to the increase of PWID rate. Furthermore, other factors may also influence epidemiologic trend of $\mathrm{HCV}$ infection within the next years and lead to changes in its epidemiology, as the role of past and current immigration, the increase in sex/drug consume-tourism, $\mathrm{HCV}$ re-infections rates in IVDA, generation of new (recombinant) GTs, as well as selection of certain GTs by the current DAAs [63-65].

This review is one of the first attempt for the collection of European HCV data to provide reliable information about the current genotype prevalence situation, and it is also a call to join efforts and encourage further observational studies on $\mathrm{HCV}$ genotype prevalence at supra- national level to gain reliable knowledge on the epidemiology of $\mathrm{HCV}$ infection. Stronger national and international efforts, including a more massive collection of data especially on risk groups and the institution of a central register to monitor the national $\mathrm{HCV}$ diagnosis rates, could surely introduce an appropriate strategyto limit HCV infection in Europe.

\section{Abbreviations}

DAA: Direct-acting antiviral; GBD: Global burden diseases project; HCV: Hepatitis C virus; IU/ml: International units per Milliliter; IVDA: Intravenous drug abuser; MSM: Man who have sex with men; PWID: People who inject drugs; RT-PCR: Reverse transcription polymerase chain reaction

\section{Acknowledgements}

Not applicable.

\section{Funding}

The Authors declare no study sponsors involvement in the study design, in the collection, analysis and interpretation of data, in the writing of the manuscript and in the decision to submit the manuscript for publication.

\section{Availability of data and materials}

Availability of data and materials.

\section{Authors' contributions}

AP, SM and GL acquired the data; AP drafted the article and contributed to conception and design; CC contributed to critical revision for important intellectual content; all authors approved the final version to be published.

\section{Competing interests}

The authors declare that they have no competing interests.

\section{Consent for publication}

Not applicable.

\section{Ethics approval and consent to participate}

Not applicable.

Received: 27 June 2016 Accepted: 2 September 2016

Published online: 12 October 2016

\section{References}

1. Cooke GS, Lemoine M, Thursz M, Gore C, Swan T, Kamarulzaman A, et al. Viral hepatitis and the Global Burden of Disease: a need to regroup. J Viral Hepat. 2013:20:600-1.

2. Omland LH, Jepsen $\mathrm{P}$, Krarup $\mathrm{H}$, et al. Increased mortality among persons infected with hepatitis C virus. Clin Gastroenterol Hepatol. 2011;9:71-8.

3. Omland LH, Krarup H, Jepsen P, et al. Mortality in patients with chronic and cleared hepatitis C viral infection: a nationwide cohort study. J Hepatol. 2010;53: $36-42$.
4. Perz JF, Armstrong GL, Farrington LA, et al. The contributions of hepatitis B virusand hepatitis $C$ virus infections to cirrhosis and primary liver cancer worldwide. J Hepatol. 2006;45:529-38.

5. Mohd Hanafiah K, Groeger J, Flaxman AD, Wiersma ST. Global epidemiology of hepatitis C virus infection: new estimates of age-specific antibody to HCV seroprevalence. Hepatology. 2013:57:1333-42.

6. Lee MH, Yang HI, Lu SN, et al. Chronic hepatitis C virus infection increases mortality from hepatic and extrahepatic diseases: a community-based longterm prospective study. J Infect Dis. 2012;206:469-77.

7. Van der Meer AJ, Veldt BJ, Feld JJ, et al. Association between sustained virological response and all-cause mortality among patients with chronic hepatitisC and advanced hepatic fibrosis. J Am Med Assoc. 2012;308:2584-93.

8. Lauer GM, Walker BD. Hepatitis C virus infection. N Engl J Med. 2001;345:41-52.

9. Muhlberger N, Schwarzer R, Lettmeier B, et al. HCV-related burden ofdisease in Europe: a systematic assessment of incidence, prevalence, morbidity, and mortality. BMC Public Health. 2009;9:34

10. Davis GL, Alter MJ, El-Serag H, Poynard T, Jennings LW. Aging of hepatitisC virus (HCV)-infected persons in the United States: a multiple cohortmodel of HCV prevalence and disease progression. Gastroenterology. 2010;138:513-21.

11. Hsu YC, Lin JT, Ho HJ, et al. Antiviral treatment for hepatitis $C$ virus infection is associated with improved renal and cardiovascular outcomes in diabetic patients. Hepatology. 2014;59:1293-302.

12. Hsu CS, Kao JH, Chao YC, et al. Interferon-based therapy reduces risk of stroke in chronic hepatitis C patients: a population-based cohort study in Taiwan. Aliment Pharmacol Ther. 2013;38:415-23.

13. Petruzziello A, Marigliano S, Loquercio G, Cozzolino A, Cacciapuoti C. Global epidemiology of Hepatitis C Virus (HCV) infection: an up-date of the distribution and circulation of HCV genotypes. World J Gastroenterol. 2016;22(34);7824-7840.

14. Razavi H, ElKhoury AC, Elbasha E, Estes C, Pasini K, Poynard T, et al. Chronic hepatitis $\mathrm{C}$ virus (HCV) disease burden and cost in the United States. Hepatology. 2013;57:2164-70.

15. Razavi H, Waked I, Sarrazin C, et al. The present and future disease burden ofhepatitis $\mathrm{C}$ virus with today's treatment paradigm. J Viral Hepat. 2014;21(Suppl. 1):34-59

16. Wedemeyer H, Duberg AS, Buti M, Rosenberg WM, Frankova S, Esmat G, et al. Strategies to manage hepatitis C virus (HCV) disease burden. J Viral Hepat. 2014;21:60-89.

17. Martin NK, Hickman M, Hutchinson SJ, Goldberg DJ, Vickerman P. Combination interventions to prevent HCV transmission among people who inject drugs: modeling the impact of antiviral treatment, needle and syringe programs, and opiate substitution therapy. Clin Infect Dis. 2013;57:S39-45.

18. Bruggmann P, Berg T, Ovrehus AL, Moreno C, Brandao Mello CE, RoudotThoraval F, et al. Historical epidemiology of hepatitis $\mathrm{C}$ virus (HCV) in selected countries. J Viral Hepat. 2014;21:5-33.

19. Cornberg M, Razavi HA, Alberti A, et al. A systematic review of hepatitis $C$ virus epidemiology in Europe, Canada and Israel. Liver Int. 2011;31 Suppl 2:30-60.

20. Wiessing L, Ferri M, Grady B, Kantzanou M, Sperle I, et al. Hepatitis C Virus Infection Epidemiology among People Who Inject Drugs in Europe: A Systematic Review of Data for Scaling Up Treatment and Prevention. PLoS ONE. 2014;9(7):e103345.

21. Blachier M, Leleu H, Peck-Radosavljevic M, Valla DC, Roudot-Thoraval F. The burden of liver disease in Europe: a review of available epidemiological data. J Hepatol. 2013;58:593-608.

22. Rantala M, van de Laar MJ. Surveillance and epidemiology of hepatitisB and C in Europe - a review. Euro Surveill. 2008;13.

23. Esteban JI, Sauleda S, Quer J. The changing epidemiology of hepatitis Cvirus infection in Europe. J Hepatol. 2008;48:148-62.

24. Timm J, Roggendorf $M$. Sequence diversity of hepatitis $C$ virus: implications for immune control and therapy. World I Gastroenterol. 2007;13:4808-17.

25. Simmonds P, Alberti A, Alter HJ, Bonino F, Bradley DW, Brechot C, et al. A proposed system for the nomenclature of hepatitis $C$ viral genotypes. Hepatology. 1994;19:1321-4.

26. Smith DB, Bukh J, Kuiken C, Muerhoff AS, Rice CM, Stapleton JT, et al. Expanded classification of hepatitis $C$ virus into 7 genotypes and 67 subtypes: updated criteria and genotype assignment Web resource. Hepatology. 2014;59:318-27.

27. Smith DB, Pathirana S, Davidson F, Lawlor E, Power J, Yap PL, et al. The origin of hepatitis C virus genotypes. J Gen Virol. 1997;78(Pt 2):321-8.

28. Institute for Health Metrics and Evaluation. GBD 2010 common questions. Seattle, WA: Institute for Health Metrics and Evaluation; 2013. 
29. Institute for Health Metrics and Evaluation. GBD 2013 protocol. Seattle, Washington: Institute for health Metrics and Evaluation; 2014

30. GBD 2005 Study. Global burden of diseases, injuries and risk factors study operations manual (final draft, January 2009). http://www.globalburden.org Accessed 5 Dec 2010

31. European Centre for Disease Prevention and Control. Annual Epidemiological Report on Communicable Diseases in Europe 2009. Report on the State of Communicable Diseases in Europe 2009, Revised Edition

32. Saizdl H, Marco A, Garcia-Guerrero J, Rivera A. Hepatitis C and B prevalence in Spanish prisons. Eur JClinMicrobiol Infect Dis. 2011;30(7):857-62.

33. Chak E, Talal A, Sherman KE, Schiff E, Saab S. Hepatitis C virus infection in the United States: an estimate of true prevalence. Liver Int. 2011;31(8):1090-101.

34. Gish RG, Afdhal NH, Dieterich DT, Reddy KR. Management of hepatitis C virus in special populations: patient and treatment considerations. Clin Gastroenterol Hepatol. 2005;3:311-8.

35. Lozano R, Naghavi M, Foreman K, et al. Global and regional mortality from 235 causes of death for 20 age groups in 1990 and 2010: a systematic analysis for the Global Burden of Disease Study 2010. Lancet. 2012;380(9859):2095-128.

36. Deuffic-Burban S, Deltenre $P$, Buti $M$, et al. Predicted effects of treatment for HCV infection vary among European countries. Gastroenterology. 2012 143(4):974-85. doi:10.1053/j.gastro.2012.05.054. Epub 2012 Aug 2.

37. Gane E, Kershenobich D, Seguin-Devaux C, et al. Strategies to manage hepatitis $C$ virus $(\mathrm{HCV}$ ) infection disease burden - volume 2. J Viral Hepat. 2015;22 Suppl 1:46-73.

38. Hatzakis A, Chulanov V, Gadano AC, et al. The present and future disease burden of hepatitis $C$ virus ( $\mathrm{HCV}$ ) infections with today's treatment paradigm - volume 2. J Viral Hepat. 2015;22 Suppl 1:26-45.

39. Sievert W, Altraif I, Razavi HA, et al. A systematic review of hepatitis C virus epidemiology in Asia, Australia and Egypt. Liver Int. 2011;31 Suppl 2:61-80

40. Kershenobich D, Razavi HA, Sanchez- Avila JF, et al. Trends and projections of hepatitis C virusepidemiology in Latin America. Liver Int. 2011;31 Suppl 2:18-29.

41. Lavanchy D. Evolving epidemiology of hepatitis $C$ virus. Clin Microbiol Infect. 2011;17(2):107-15.

42. Hope VD, Eramova I, Capurro D, Donoghoe MC. Prevalence and estimation of hepatitis B and C infections in the WHO European Region:a review of data focusing on the countries outside the European Union and the European Free Trade Association. Epidemiol Infect. 2014;142(2):270-86.

43. Sypsa V, Touloumi G, Tassopoulos NC, Ketikoglou I, Vafiadis I, Hatzis G, et al. Reconstructing and predicting the hepatitis C virus epidemic in Greece: increasing trends of cirrhosis and hepatocellular carcinoma despite the decline in incidence of HCV infection. J Viral Hepat. 2004;11:366-74.

44. Meffre C, Le Strat Y, Delarocque-Astagneau E, Dubois F, Antona D, Lemasson JM, et al. Prevalence of hepatitis $B$ and hepatitis $C$ virus infections in France in 2004: social factors are important predictors after adjusting for known risk factors. J Med Virol. 2010;82:546-55.

45. Denniston MM, Jiles RB, Drobeniuc J, Klevens RM, Ward JW, Mc Quillan GM, et al. Chronic hepatitis C virus infection in the United States, National Health and Nutrition Examination Survey 2003 to 2010. Ann Intern Med. 2014;160:293-300.

46. Flisiak R, Halota W, Horban A, Juszczyk J, Pawlowska M, Simon K. Prevalence and risk factors of HCV infection in Poland. Eur J Gastroenterol Hepatol. 2011;23:1213-7.

47. Garcia-Fulgueiras A, Garcia-Pina R, Morant C, et al. Burden of disease related to hepatitis $C$ and hepatitis B in Spain: a methodological challenge of an unfolding health problem. J Viral Hepat. 2011;18:e453-60.

48. Kartashev V, Doring M, Nieto L, Coletta E, Kaiser R, Sierra S. New Findings in HCV Genotype Distribution in selected West European, Russian and Israeli Regions. J Clin Virol. 2015;(In press).

49. May S, Ngui SL, Collins S, Lattimore S, Ramsay M, Tedder RS, et al. Molecular epidemiology of newly acquired hepatitis $C$ infections in England 2008-2011: genotype, phylogeny and mutation analysis. J Clin Virol. 2015;64:6-11. 44430

50. Pybus $G$, Cochrane A, Holmes EC, Simmonds P. The hepatitis C virus epidemic among injecting drug users. Infect Genet Evol. 2005;5:131-9.

51. Roman F, Hawotte K, Struck D, Ternes AM, Servais JY, Arendt V, et al. C Hepatitis virus genotypes distribution and transmission risk factors in Luxembourg from 1991 to 2006. World J Gastroenterol. 2008;14:1237-43.

52. Messina JP, Humphreys I, Flaxman A, Brown A, Cooke GS, Pybus OG, et al. Global distribution and prevalence of hepatitis $C$ virus genotypes. Hepatology. 2015;61:77-87.
53. Ansaldi F, Orsi A, Sticchi L, Bruzzone B, Icardi G. C Hepatitis virus in the new era: perspectives in epidemiology, prevention, diagnostics and predictors of response to therapy. World J Gastroenterol. 2014;20:9633-52.

54. Gower E, Estes C, Blach S, Razavi-Shearer K, Razavi H. Global epidemiology and genotype distribution of the hepatitis $C$ virus infection. J Hepatol. 2014;61:545-57.

55. Marascio N, Liberto M, Barreca G, Zicca E, Quirino A, Lamberti A, et al. Update on epidemiology of HCV in Italy: focus on the Calabria Region. BMC Infect Dis. 2014;14(5):S2.

56. Roffi L, Ricci A, Ogliari C, Scalori A, Minola E, Colloredo G, et al. HCV genotypes in Northern Italy: a survey of 1368 histologically proven chronic hepatitis C patients. J Hepatology. 1998;29:701-6.

57. Petruzziello A, Coppola N, Diodato AM, lervolino V, Azzaro R, et al. Age and gender distribution of hepatitis $C$ virus genotypes in the metropolitan area of Naples. Intervirology. 2013;56(3):206-12.

58. Petruzziello A, Coppola N, Loquercio G, Marigliano S, Giordano M, et al. Distribution pattern of Hepatitis C Virus (HCV) genotypes and correlation with viral load and risk factors in chronic positive patients. Intervirology. 2014;57:311-8.

59. Marascio N, Ciccozzi M, Equestre M, Lo Presti A, Costantino A, Cella E, et al. Back to the origin of $\mathrm{HCV} 2 \mathrm{C}$ subtype and spreading to the Calabria region (Southern Italy) over the last two centuries: a phylogenetic study. Infect Genet Evol. 2014;26:352-8.

60. de Bruijne J, Schinkel J, Prins M, Koekkoek SM, Aronson SJ, van Ballegooijen MW, et al. Emergence of hepatitis C virus genotype 4: phylogenetic analysis reveals three distinct epidemiological profiles. J ClinMicrobiol. 2009;47:3832-8

61. Caro-Murillo AM, Castilla J, Perez-Hoyos S, Miro JM, Podzamczer D, Rubio R, et al. Spanish cohort of naive HIV-infected patients (CoRIS): rationale, organization and initial results. Enferm Infect Microbiol Clin. 2007;25:23-31.

62. Hagan $H$, Jordan AE, Neurer J, Cleland CM. Incidence of sexually transmitted hepatitis $C$ virus infection in HIV-positive men who have sex with men. AIDS. 2015;29:2335-45.

63. Beijer U, Wolf A, Fazel S. Prevalence of tuberculosis, hepatitis C virus, and HIV in homeless people: a systematic review and meta-analysis. Lancet Infect Dis. 2012;12:859-70.

64. Sacks-Davis R, Aitken CK, Higgs P, Spelman T, Pedrana AE, Bowden S, et al. High rates of hepatitis $C$ virus reinfection and spontaneous clearance of reinfection in people who inject drugs: a prospective cohort study. PLoS One. 2013;8:e80216

65. Weinbaum CM, Sabin KM, Santibanez SS. Hepatitis B, hepatitis C, and HIV in correctional populations: a review of epidemiology and prevention. AIDS. 2005;19 Suppl 3:S41-6.

\section{Submit your next manuscript to BioMed Central and we will help you at every step:}

- We accept pre-submission inquiries

- Our selector tool helps you to find the most relevant journal

- We provide round the clock customer support

- Convenient online submission

- Thorough peer review

- Inclusion in PubMed and all major indexing services

- Maximum visibility for your research

Submit your manuscript at www biomedcentral.com/submit
C) Biomed Central 